GRASAS Y ACEITES, 61 (2),

ABRIL-JUNIO, 183-190, 2010,

ISSN: 0017-3495

Dol: 10.3989/gya.108909

\title{
Lipid hydrolysis and oxidation in farmed gilthead seabream (Sparus aurata) slaughtered and chilled under different icing conditions
}

\author{
By Santiago P. Aubourg, ${ }^{*}$ Victoria Álvarez and Javier Pena \\ Food Technology Department, Instituto de Investigaciones Marinas (CSIC). Vigo (Spain) \\ ( ${ }^{\star}$ Corresponding author: saubourg @iim.csic.es)
}

\section{RESUMEN}

Hidrólisis y oxidación lipídicas en dorada (Sparus aurata) de cultivo sacrificada y conservada en distintos tipos de hielo.

Este trabajo estudia el sacrificio y conservación en hielo (hasta 14 días) de dorada (Sparus aurata). Para ello, se aplicó hielo líquido $(\mathrm{SI})$ de forma comparativa con hielo tradicional $(\mathrm{FI})$ en escamas. Se analizó el desarrollo de hidrólisis y oxidación lipídicas, procediéndose a su comparación con la evaluación sensorial y la formación de trimetilamina (TMA). Se observó una importante pérdida de calidad de acuerdo con la valoración sensorial y la formación de TMA. Sin embargo, la alteración lipídica fue baja, a tenor de los índices ensayados (hidrólisis lipídica; oxidación lipídica primaria, secundaria y terciaria). No se detectaron desarrollo de olor rancio ni pérdida de ácidos grasos poliinsaturados. El empleo de SI en esta especie resultó ser útil al objeto de inhibir la pérdida de calidad; así, se observó un incremento en el tiempo de vida útil y una inhibición en la formación de TMA y ácidos grasos libres.

PALABRAS CLAVE: Acuicultura - Alteración lipídica Dorada - Hielo líquido - Refrigeración - Sacrificio.

\section{SUMMARY}

Lipid hydrolysis and oxidation in farmed gilthead seabream (Sparus aurata) slaughtered and chilled under different icing conditions.

This work focuses on the slaughtering and chilled storage (up to 14 days) related to the commercialization of fresh farmed gilthead seabream (Sparus aurata). A slurry ice (SI) system was applied and evaluated in comparison to traditional flake ice (FI). Lipid hydrolysis and oxidation were analyzed and compared to sensory acceptance and trimethylamine (TMA) formation. An important quality loss could be assessed in fish during slaughtering and chilling storage, according to sensory assessment and TMA formation. However, lipid damage development was found relatively low, in agreement to the different lipid quality indexes checked (lipid hydrolysis; primary, secondary and tertiary lipid oxidation). No development of rancid odor and no polyunsaturated fatty acid losses were detected. The employment of SI as a slaughtering and chilling strategy was found useful to inhibit quality loss in gilthead seabream resulting in a shelf life increase and a TMA and free fatty acid formation inhibition.

KEY-WORDS: Chilling - Farming - Gilthead seabream Lipid damage - Slaughtering - Slurry ice.

\section{INTRODUCTION}

Different mechanisms have been found responsible for fish deterioration during chilled storage (Whittle et al., 1990; Olafsdóttir et al., 1997). Among them, the lipid fraction has been reported to undergo hydrolysis and oxidation reactions that can lead to important losses in sensory and nutritional qualities with an important impact on its commercial value (Harris and Tall, 1994; Chaouqy et al., 2008).

In order to avoid fish damage development during chilled storage, recent research accounts for advanced strategies. One such technology is slurry ice (SI) which, when employed in the place of traditional flake ice $(\mathrm{FI})$ has shown many advantages such as a lower storage temperature, faster cooling, lower physical damage to the product and better heat exchange power. As a result, the application of this chilling strategy has led to an important inhibition of autolysis development, microbiological activity and lipid oxidation in different kinds of marine products (Yamada et al., 2002; Medina et al., 2009).

For some decades now, fish technologists and the fish trade have been especially attracted by aquaculture development as a source of fish products. Among cultivated fish, gilthead seabream (Sparus aurata) deserves great attention because of its increasing production in Mediterranean countries such as Greece, Turkey and Spain (FAO, 2007). Previous research carried out during the chilled storage of this species accounts for changes in sensory (Kyrana et al., 1997; Erkan, 2007), microbial (López-Caballero et al., 2002; Cakli et al., 2006; Özogul et al., 2007), physical (Alasalvar et al., 2002; Lougovois et al., 2003) and chemical (Tejada et al., 2003; Caballero et al., 2009) properties. Concerning the lipid fraction, most research on gilthead seabream has been focused on the effect of the diet provided (Yildiz et al., 2008; Fountoulaki et al., 2009) and the harvesting season (Grigorakis et al., 2003; Senso et al., 2007) on the fatty acid profile of the fish product; however, research concerning lipid damage during the chilled storage of this species has been scarce and complementary to other kinds of quality analyses (Kyrana et al., 1997; Grigorakis et al., 2003; Cakli et al., 2006). 
The present work focuses on the slaughtering and chilling steps related to the commercialization of farmed gilthead seabream as a fresh product. An SI system was applied and evaluated comparatively to traditional FI with the objective of extending shelf life. In this study, lipid hydrolysis and oxidation were analyzed, sensory acceptance was compared and trimethylamine formation (microbial activity) was undertaken.

\section{MATERIALS AND METHODS}

\subsection{Icing systems}

Two different icing systems ( $\mathrm{FI}$ and $\mathrm{SI}$ ) were employed for the fish slaughter and chilled storage.

FI was prepared with an Icematic F100 Compact device (Castelmac SPA, Castelfranco, Italy). The temperature of the $\mathrm{FI}$ was $-0.5^{\circ} \mathrm{C}$, with the temperature of the fish in the range of $0{ }^{\circ} \mathrm{C}$ to $-0.5^{\circ} \mathrm{C}$.

SI was prepared using a FLO-ICE prototype (Kinarca S.A.U., Vigo, Spain). The composition of the SI binary mixture was $40 \%$ ice/ $60 \%$ water, prepared from filtered seawater (salinity: $3.3 \%$ ). The temperature of the SI mixture was $-1.5{ }^{\circ} \mathrm{C}$, being the temperature of the fish in the range of $-1.0^{\circ} \mathrm{C}$ to $-1.5^{\circ} \mathrm{C}$.

\subsection{Fish material, slaughter and chilled storage}

Sixty specimens of farmed gilthead seabream (Sparus aurata) (individual weight range: 0.42-0.50 $\mathrm{kg}$; individual length range: $28-30 \mathrm{~cm}$ ) were obtained (day 0 ) from an aquaculture facility (Cultipeix $S$. L., Valencia, Spain) and slaughtered at the farm by immersion either in $\mathrm{FI}$ (30 individuals) or $\mathrm{SI}$ (30 individuals). Individuals were kept under such conditions for 24 hours until arrival at the laboratory. At this time (day 1), six individuals belonging to each icing condition were separated and taken for sensory and chemical analyses as starting fish. Specimens from each icing condition were divided into three groups (two individuals in each group) which were studied separately $(n=3)$. The remaining fish were placed in an isothermal room at $2{ }^{\circ} \mathrm{C}$ and were surrounded by either $\mathrm{FI}$ or SI at a 1:1 fish to ice ratio. Fish sampling was then continued on days $4,7,11$ and 14 of icing treatment, according to the same sampling design $(n=3)$. Throughout the experiment, both the FI or SI were renewed when required.

\subsection{Sensory analyses}

Sensory analysis was conducted by a sensory panel consisting of five experienced judges, according to guidelines concerning fresh and refrigerated fish (DOCE, 1989). Sensory assessment of the fish included the examination of the following parameters: skin, eyes, external odor, gills, consistency and flesh odor (Table 1). Four categories were ranked: highest quality $(E)$, good quality $(A)$, fair quality $(B)$ and unacceptable quality $(\mathrm{C})$.

The panellists included in this study had been involved in sensory analysis of different fish species for ten years. Previously to the present experiment, the panellists were specially trained with chilled gilthead seabream. At each sampling time, the fish specimens were presented to panellists and were scored individually. The panel members shared samples tested.

\subsection{Trimethylamine (TMA) formation}

Trimethylamine-nitrogen (TMA-N) values were determined by means of the picrate method, this

Table 1

Scale employed for evaluating the freshness degree of gilthead seabream

\begin{tabular}{|c|c|c|c|c|}
\hline Attribute & Highest quality (E) & Good quality (A) & Fair quality (B) & Unacceptable (C) \\
\hline Skin & $\begin{array}{l}\text { Very intense } \\
\text { pigmentation; transparent } \\
\text { mucus }\end{array}$ & $\begin{array}{l}\text { Milky mucus; insignificant } \\
\text { pigmentation losses }\end{array}$ & $\begin{array}{l}\text { Slightly greyish mucus; } \\
\text { pigmentation without } \\
\text { shine }\end{array}$ & $\begin{array}{l}\text { Widely opaque mucus; } \\
\text { important pigmentation } \\
\text { losses }\end{array}$ \\
\hline Eyes & $\begin{array}{l}\text { Convex; transparent } \\
\text { cornea; bright and black } \\
\text { pupil }\end{array}$ & $\begin{array}{l}\text { Convex and slightly } \\
\text { sunken; slightly } \\
\text { opalescent cornea; black } \\
\text { and cloudy pupil }\end{array}$ & $\begin{array}{l}\text { Flat; opalescent cornea; } \\
\text { opaque pupil }\end{array}$ & $\begin{array}{l}\text { Concave and milky } \\
\text { cornea; internal organs } \\
\text { blurred }\end{array}$ \\
\hline External odor & $\begin{array}{l}\text { Sharply seaweedy and } \\
\text { shellfish smell }\end{array}$ & $\begin{array}{l}\text { Weakly seaweedy and } \\
\text { shellfish smell }\end{array}$ & Incipiently putrid or rancid & Putrid or rancid \\
\hline Gills & $\begin{array}{l}\text { Brightly red; without odor; } \\
\text { lamina perfectly } \\
\text { separated }\end{array}$ & $\begin{array}{l}\text { Rose coloured; without } \\
\text { odour; lamina adhered in } \\
\text { groups }\end{array}$ & $\begin{array}{l}\text { Slightly pale; incipient } \\
\text { fishy odor; lamina } \\
\text { adhered in groups }\end{array}$ & $\begin{array}{l}\text { Grey-yellowish color; } \\
\text { intense ammonia odor; } \\
\text { lamina totally adhered }\end{array}$ \\
\hline Consistency & $\begin{array}{l}\text { Presence or partial } \\
\text { disappearance of rigor } \\
\text { mortis symptoms }\end{array}$ & $\begin{array}{l}\text { Firm and elastic; pressure } \\
\text { signs disappear } \\
\text { immediately and } \\
\text { completely }\end{array}$ & $\begin{array}{l}\text { Presence of mechanical } \\
\text { signs; elasticity notably } \\
\text { reduced }\end{array}$ & $\begin{array}{l}\text { Important shape changes } \\
\text { due to mechanical factors }\end{array}$ \\
\hline Flesh odour & $\begin{array}{l}\text { Sharply seaweedy and } \\
\text { shellfish smell }\end{array}$ & $\begin{array}{l}\text { Weakly seaweedy and } \\
\text { shellfish smell }\end{array}$ & Incipiently putrid or rancid & Putrid or rancid \\
\hline
\end{tabular}


including a spectrophotometric $(410 \mathrm{~nm})$ assessment (Beckman Coulter DU 640, London, UK) (Tozawa et al., 1971). This involves the preparation of a $5 \%$ $(\mathrm{w} / \mathrm{v})$ trichloroacetic acid extract of fish muscle. The results were expressed as mg TMA-N/ $100 \mathrm{~g}$ muscle.

\subsection{Lipid hydrolysis}

Lipids were extracted by the Bligh and Dyer (1959) method. Quantification results were expressed as $\mathrm{g}$ lipid/ $100 \mathrm{~g}$ muscle.

Free fatty acid (FFA) content was determined in the lipid extract of the fish muscle by the Lowry and Tinsley (1976) method based on complex formation with cupric acetate-pyridine followed by spectrophotometric $(715 \mathrm{~nm})$ assessment. Results were expressed as g FFA/ $100 \mathrm{~g}$ lipids.

\subsection{Lipid oxidation}

The peroxide value (PV) was determined in the lipid extract of the muscle according to the ferric thiocyanate method (Chapman and McKay, 1949). Results were expressed as meq active oxygen/ kg lipids.

The thiobarbituric acid index (TBA-i) was determined in a $5 \%(\mathrm{w} / \mathrm{v})$ trichloracetic acid extract of the fish muscle (Vyncke, 1970). Results were expressed as mg malondialdehyde/ $\mathrm{kg}$ muscle.

Formation of fluorescent compounds was determined in the lipid extract of the muscle by measurements at $393 / 463 \mathrm{~nm}$ and $327 / 415 \mathrm{~nm}$ as previously described (Aubourg et al., 1998). The relative fluorescence (RF) was calculated as follows: $R F=F / F_{s t}$, where $F$ is the fluorescence measured at each excitation/emission maximum, and $\mathrm{F}_{\mathrm{st}}$ is the fluorescence intensity of a quinine sulphate solution $\left(1 \mu \mathrm{g} / \mathrm{ml}\right.$ in $\left.0.05 \mathrm{M} \mathrm{H}_{2} \mathrm{SO}_{4}\right)$ at the corresponding wavelength. The fluorescence ratio (FR) was calculated as the ratio between the two RF values: $\mathrm{FR}=\mathrm{RF}_{393 / 463} \mathrm{~nm} / \mathrm{RF}_{327 / 415} \mathrm{~nm}$.

Browning development was measured in the lipid extract by spectrophotometric $(420 \mathrm{~nm})$ assessment. Results shown were calculated according to the formula: $\mathrm{B} \times \mathrm{V} / \mathrm{w}$, where $\mathrm{B}$ is the absorbance lecture obtained, $\mathrm{V}$ is the volume $(\mathrm{ml})$ of the organic extract and $\mathrm{w}$ is the weight $(\mathrm{g})$ of the fish muscle employed (Smith et al., 1990).

\subsection{Fatty acid analysis}

Lipid extracts were converted into fatty acid methyl esters (FAME) by employing acetyl chloride and then analyzed by gas chromatography according to a previous procedure (Aubourg et al., 1996). FAME were analyzed by means of a PerkinElmer 8700 chromatograph employing a fused silica capillary column SP-2330 $(0.25 \mathrm{~mm}$ i.d. x 30 $\mathrm{m}$, Supelco Inc., Bellefonte, PA, USA). Nitrogen at $10 \mathrm{psi}$ as carrier gas and flame ionization detector (FID) at $250{ }^{\circ} \mathrm{C}$ were used. Peaks corresponding to fatty acids were identified by comparison of their retention times with standard mixtures (Larodan, Qualmix Fish, Malmo, Sweden; Supelco, FAME Mix, Bellefonte, PA, USA). Peak areas were automatically integrated, 19:0 fatty acid being used as internal standard for quantitative analysis. The concentration of each fatty acid was calculated as $\mathrm{g} / 100 \mathrm{~g}$ total FAME.

\subsection{Statistical analyses}

Data $(n=3)$ obtained from the different sensory and chemical analyses were subjected to the ANOVA method to explore differences in two different ways: icing condition (FI/SI comparison) and icing time (Statsoft Inc., Statistica, version 6.0, 2001). Comparison of means was performed using the least-square differences (LSD) test. Confidence interval at the 95\% level $(p<0.05)$ was considered in all cases. Correlation analysis among parameters was also carried out. Linear fittings are expressed; otherwise, the kind of fitting is mentioned.

\section{RESULTS AND DISCUSSION}

\subsection{Sensory evaluation and microbial activity assessment}

As long as the storage time increased, a progressive sensory acceptance decrease could be observed in fish corresponding to both icing conditions (Table 2). However, some differences could be assessed between both fish groups. Thus, a shelf life time of 11 days was obtained for individuals kept under $\mathrm{FI}$ conditions, while their counterparts stored under SI system were still acceptable at the end of the experiment. External odor (putrid odor development) and gills (color and odor) were found to be limiting factors.

The absence of rancid odor development can be partially explained on the basis of the lipid content obtained $(0.75-1.20 \mathrm{~g} / 100 \mathrm{~g}$ muscle), this being lower than that reported for the same farmed species in previous research (Kyrana et al., 1997; Alasalvar et al., 2002; Grigorakis et al., 2003; Özogul et al., 2007; Yildiz et al., 2008). Lipid content differences in muscle can be justified as a result of a different feed composition. Present results on lipid content are in agreement with those previously obtained for this species under wild conditions (Alasalvar et al., 2002; Yildiz et al., 2008).

Shelf life values obtained in this study for gilthead seabream kept under traditional flake ice can be considered in agreement with previous research. Thus, previous reports account for a shelf life time of 9-12 days (Cakli et al., 2006), 12 days (Erkan, 2007), 14 days (Kyrana et al., 1997) and 18 days (Özogul et al., 2007). Differences among experiments can be explained as a result of different factors such as fish-to-ice ratio, fish size, slaughtering condition, starting raw fish quality, etc.

Concerning the employment of the SI system, it is worth pointing out that this treatment has not 
Table 2

Comparative sensory evaluation of fresh gilthead seabream subjected to slaughter and chilled storage in flake ice (FI) or slurry ice (SI), respectively*

\begin{tabular}{|c|c|c|c|c|c|c|c|c|c|c|}
\hline \multirow[b]{3}{*}{ Attribute } & \multicolumn{10}{|c|}{ Icing Time (days) } \\
\hline & \multicolumn{2}{|c|}{1} & \multicolumn{2}{|c|}{4} & \multicolumn{2}{|c|}{7} & \multicolumn{2}{|c|}{11} & \multicolumn{2}{|c|}{14} \\
\hline & FI & SI & $\mathbf{F I}$ & SI & FI & SI & FI & SI & $\mathbf{F I}$ & SI \\
\hline Skin & $E$ & $E$ & $A$ & $E$ & $A$ & $E$ & $A$ & $A$ & $A$ & $A$ \\
\hline Eyes & $E$ & $E$ & $A$ & $A$ & $A$ & $A$ & $\mathrm{~B}$ & $B$ & $\mathrm{~B}$ & $B$ \\
\hline External odor & $E$ & $E$ & $A$ & $A$ & $\mathrm{~B}$ & $A$ & $\mathrm{~B}$ & $A$ & $\mathrm{C}$ & B \\
\hline Gills & $E$ & $E$ & $A$ & $E$ & $\mathrm{~B}$ & $A$ & $\mathrm{~B}$ & $A$ & $\mathrm{C}$ & B \\
\hline Consistency & $E$ & $E$ & $A$ & $E$ & $A$ & $E$ & $\mathrm{~B}$ & $A$ & $\mathrm{~B}$ & $A$ \\
\hline Flesh Odor & $E$ & $E$ & $E$ & $E$ & $A$ & $A$ & $A$ & $A$ & $B$ & $A$ \\
\hline
\end{tabular}

* Freshness categories as expressed in Table 1.

produced a cloudy appearance in the eyes in this study. This problem was previously detected (Huidobro et al., 2001) and could be attributed to the employment of a relatively low temperature (round $-2.2^{\circ} \mathrm{C}$ ); however, quality benefits were found by Huidobro et al. (2001) from the physico-chemical point of view when SI was used as a slaughter method for gilthead seabream in replacement of the FI system.

In a recent research (Kilinc et al., 2007), SI conditions provided some advantages when applied to gilthead seabream in replacement of Fl. Thus, both icing conditions were applied as a cooling pretreatment for $2 \mathrm{~h}$ before a further refrigerated storage at $4{ }^{\circ} \mathrm{C}$ up to 15 days. As a result, individuals previously treated under SI conditions showed a higher shelf life time (15 days) than their counterparts kept under FI condition (13 days) during the refrigerated storage.

Microbial activity was measured in the present study by the TMA formation (Figure 1). In both kinds of fish, an increasing TMA formation could be depicted as long as the storage time increased $\left(r^{2}=0.93-0.94\right.$, quadratic fitting); however, only fair correlation values $\left(r^{2}=0.80-0.90\right)$ could be observed with the different sensory attributes. Differences between individuals from both icing conditions could only be observed at the end of the experiment (day 14), when higher $(p<0.05)$ TMA values were obtained for individuals corresponding to $\mathrm{FI}$ conditions.

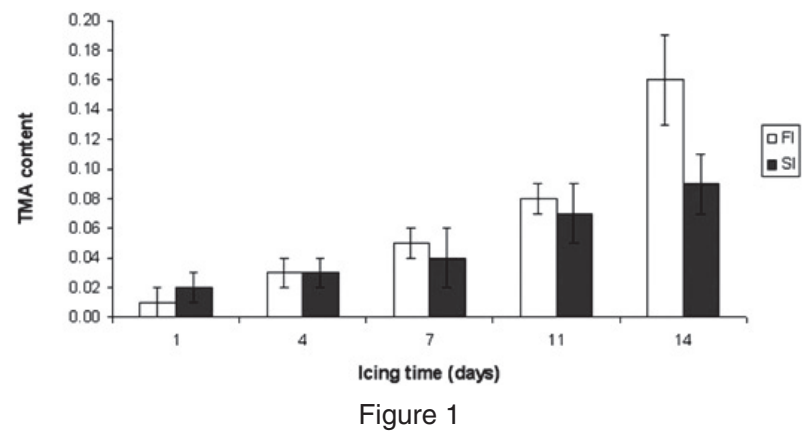

Trimethylamine (TMA) formation in gilthead seabream after slaughtering and chilled storage in flake ice (FI) or slurry ice

$(\mathrm{SI})^{*}$, respectively. * Average values (mg TMA-N/ $100 \mathrm{~g}$ muscle) of three $(n=3)$ independent determinations. Standard deviations are indicated by bars.
Results obtained in fish kept under the FI system can be considered low when compared to previous related research concerning the same farmed species (Cakli et al., 2006; Erkan, 2007). Since TMA is produced during chilled storage from trimethylamine oxide (TMAO) by bacterial enzyme reduction, present results could be explained on the basis of a low TMAO value in the muscle. In this sense, the TMAO content in farmed fish muscle has shown a great dependence on feed composition (Kyrana et al., 1997) and differences among different edible parts of the fish body (Álvarez et al., 2009).

Previous research has also shown a lower TMA formation in gilthead seabream as a result of replacing $\mathrm{FI}$ with $\mathrm{SI}$ as cooling system (Kilinc et al., 2007); in this cooling pre-treatment experiment, refrigerated $\left(4{ }^{\circ} \mathrm{C}\right)$ gilthead seabream individuals previously treated under $\mathrm{FI}$ conditions reflected a higher TMA formation than their counterparts corresponding to the SI system.

\subsection{Lipid hydrolysis}

No significant $(p>0.05)$ FFA formation could be assessed in either kinds of iced fish during the 1-7 day icing period (Figure 2). At day 11, an important FFA formation $(p<0.05)$ could be depicted in individuals corresponding to FI conditions; for SI-fish, a marked hydrolysis development $(p<$ 0.05 ) could be observed only at the end of the experiment. Comparison between both kinds of fish led to a higher $(p<0.05)$ FFA formation in FIindividuals during the 11-14 day period.

FFA formation has been reported to be produced during the first stages of the chilling process (up to day 9, approximately) as a result of endogenous enzyme (namely lipases and phospholipases) activity (Pigott and Tucker, 1990; Whittle et al., 1990). Later on, microbial activity should gain importance, so that FFA formation is then mostly produced as a result of bacterial catabolic processes. According to this profile, present results on FFA formation in gilthead seabream show that endogenous enzyme activity has been negligible, while the microbial contribution has been significant during the 11-14 day period for Fl-fish and at the 
end of the experiment for SI-fish. According to this microbial activity on FFA formation, a good correlation value was obtained between FFA and TMA contents $\left(r^{2}=0.86-0.93\right)$.

An important aspect to be taken into account related to the microbial activity, and accordingly, to FFA formation is the presence of salt in the SI system. Thus, previous research has shown an important inhibitory effect of salt on lipid hydrolysis development in stored fish (Aubourg and Ugliano, 2002; Chaouqy et al., 2008). Therefore, an important role of salt can be inferred on the different developments of lipid hydrolysis in both kinds of fish in the present study.

Regarding the sensory assessment, FFA accumulation has been associated in some extent to the lack of sensory acceptability, being strongly interrelated with off-odor development (Refsgaard et al., 2000). However, poor correlation values were obtained in the present experiment for the FFA content with the different sensory attributes $\left(r^{2}=0.68-0.87\right)$ and with the external odor in particular $\left(r^{2}=0.75-0.82\right)$. In this sense, it has to be taken into account that the external odor detected by the sensory panel was judged as putrid odor and not as rancid odor. Accordingly, a better correlation of external odor was obtained with the TMA $\left(r^{2}=0.80-0.90\right.$, above mentioned) than with FFA formation.

In addition to the low lipid content, the absence of rancid odor development in the present study can also be explained on the basis that the final FFA values can be considered low when compared to FFA values obtained during storage under $\mathrm{FI}$ conditions for the same farmed species (Kyrana et al., 1997) or related farmed species such as blackspot seabream (Pagellus bogaraveo; Álvarez et al., 2009) and sea bass (Dicentrarchus labrax; Pena et al., 2009). While the formation of FFA itself does not lead to nutritional losses, its assessment is deemed important when considering the development of rancidity. Thus, a pro-oxidant effect of FFA on lipid matter has been proposed and explained on the basis of a catalytic effect of the carboxyl group on the formation of free radicals by the decomposition of hydroperoxides (Miyashita and Takagi, 1986; Aubourg, 2001). In addition, FFA are known to oxidize faster than higher-molecular weight lipid classes (namely, triglycerides and phospholipids) by providing a greater accessibility (lower steric hindrance) to oxygen and other prooxidant molecules (Labuza, 1971).

\subsection{Lipid oxidation}

Lipid oxidation was studied by means of different quality indexes corresponding to different steps included in the development of the lipid oxidation mechanism.

Peroxide formation (primary oxidation) was evident at day 7 in both kinds of fish samples, according to a marked content increase $(p<0.05)$ (Table 3). At the end of the experiment, an

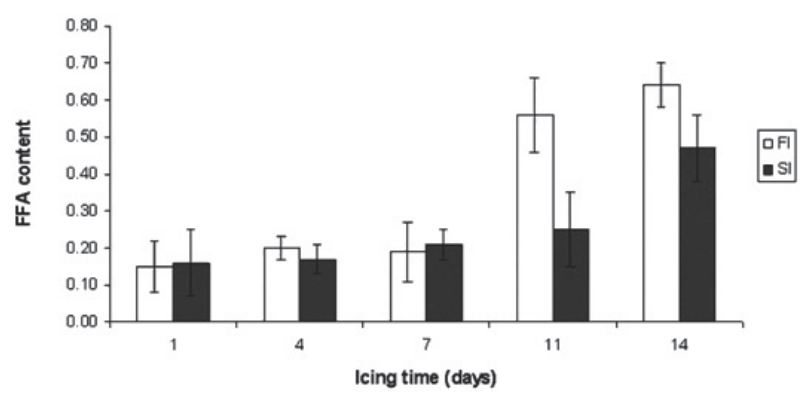

Figure 2

Free fatty acid (FFA) formation in gilthead seabream after slaughtering and chilled storage in flake ice (FI) or slurry ice $(\mathrm{SI})^{*}$, respectively. * Average values ( $\mathrm{g} / 100 \mathrm{~g}$ lipids) of three $(n=3)$ independent determinations. Standard deviations are indicated by bars.

important peroxide content decrease is observed, being likely to be produced as a result of partial peroxide breakdown into other kinds of lipid oxidation compounds (Pokorný, 1981; Aubourg, 1999). Highest mean PV obtained (days 7 and 11 for individuals corresponding to $\mathrm{SI}$ and $\mathrm{FI}$, respectively) remain below a 10 value and can not be considered especially high.

Concerning secondary lipid oxidation compound formation (Table 3), the assessment of thiobarbituric acid reactive substances (TBARS) showed a low and progressive formation in both kinds of fish with icing time $\left(r^{2}=0.88-0.90\right.$, quadratic fitting); a significant increase was only observed at the 11-14 day period for individuals from $\mathrm{FI}$ and SI conditions. Throughout the whole experiment, no differences $(p>0.05)$ could be defined between the two kinds of fish.

Previous research concerning the chilled storage of gilthead seabream under $\mathrm{FI}$ conditions accounts for a low (Kyrana et al., 1997) and a marked (Grigorakis et al., 2003; Cakli et al., 2006) TBA-i increase with chilling time. In such cases, starting and 14-days-storage values were markedly higher than in the present study. Previous research has also shown a lower TBARS formation as a result of replacing $\mathrm{FI}$ by $\mathrm{SI}$ as cooling system (Kilinc et al., 2007); in this cooling pre-treatment experiment, refrigerated gilthead seabream individuals previously treated under FI conditions reflected a higher secondary lipid oxidation compound formation.

Among the different chemical lipid oxidation parameters studied in the present experiment, secondary lipid oxidation compounds (TBA-i) are known to be the most closely related to the formation of rancid flavors (White, 1994). In the present experiment, the TBARS formation was low and can be considered partially responsible for the fact that no rancid development was detected during the sensory analysis. Accordingly, poor correlation values were obtained between the TBA-i and the external odor $\left(r^{2}=0.86-0.67\right)$.

Formation of tertiary lipid oxidation compounds was measured according to the fluorescence and browning development in lipid extracts from 
Table 3

Assessment of lipid oxidation development* in gilthead seabream after slaughtering and chilled storage in flake ice (FI) or slurry ice $(\mathrm{SI})^{\star \star}$, respectively

\begin{tabular}{|c|c|c|c|c|c|c|c|c|}
\hline \multirow{2}{*}{$\begin{array}{l}\text { Icing time } \\
\text { (days) }\end{array}$} & \multicolumn{2}{|c|}{ Peroxide value } & \multicolumn{2}{|c|}{$\begin{array}{c}\text { Thiobarbituric acid } \\
\text { index }\end{array}$} & \multicolumn{2}{|c|}{$\begin{array}{c}\text { Fluorescence } \\
\text { formation }\end{array}$} & \multicolumn{2}{|c|}{$\begin{array}{c}\text { Browning } \\
\text { development }\end{array}$} \\
\hline & FI & SI & FI & SI & FI & SI & FI & SI \\
\hline 1 & $\begin{array}{l}2.95 \mathrm{a} \\
(0.84)\end{array}$ & $\begin{array}{l}2.84 \mathrm{a} \\
(1.35)\end{array}$ & $\begin{array}{c}0.12 \mathrm{ab} \\
(0.08)\end{array}$ & $\begin{array}{c}0.14 \mathrm{ab} \\
(0.06)\end{array}$ & $\begin{array}{c}2.61 \\
(0.56)\end{array}$ & $\begin{array}{c}2.50 \\
(0.85)\end{array}$ & $\begin{array}{c}1.10 \\
(0.10)\end{array}$ & $\begin{array}{c}1.01 \\
(0.20)\end{array}$ \\
\hline 4 & $\begin{array}{l}2.80 \mathrm{a} \\
(1.04)\end{array}$ & $\begin{array}{l}2.82 \mathrm{a} \\
(1.69)\end{array}$ & $\begin{array}{l}0.06 \mathrm{a} \\
(0.01)\end{array}$ & $\begin{array}{l}0.09 \mathrm{a} \\
(0.02)\end{array}$ & $\begin{array}{c}2.72 \\
(0.97)\end{array}$ & $\begin{array}{c}2.69 \\
(1.12)\end{array}$ & $\begin{array}{c}1.09 \\
(0.11)\end{array}$ & $\begin{array}{c}1.05 \\
(0.11)\end{array}$ \\
\hline 7 & $\begin{array}{l}6.46 \mathrm{~b} \\
(1.54)\end{array}$ & $\begin{array}{l}8.13 c \\
(0.80)\end{array}$ & $\begin{array}{l}0.08 \mathrm{a} \\
(0.05)\end{array}$ & $\begin{array}{l}0.12 \mathrm{a} \\
(0.03)\end{array}$ & $\begin{array}{l}3.21 \\
(0.77)\end{array}$ & $\begin{array}{l}3.13 \\
(0.96)\end{array}$ & $\begin{array}{c}1.13 \\
(0.12)\end{array}$ & $\begin{array}{c}1.09 \\
(0.12)\end{array}$ \\
\hline 11 & $\begin{array}{l}6.69 \mathrm{~b} \\
(1.41)\end{array}$ & $\begin{array}{c}4.37 \mathrm{ab} \\
(0.97)\end{array}$ & $\begin{array}{l}0.19 b \\
(0.06)\end{array}$ & $\begin{array}{l}0.22 b \\
(0.03)\end{array}$ & $\begin{array}{l}3.15 \\
(0.96)\end{array}$ & $\begin{array}{c}3.04 \\
(1.13)\end{array}$ & $\begin{array}{c}1.20 \\
(0.12)\end{array}$ & $\begin{array}{c}1.17 \\
(0.13)\end{array}$ \\
\hline 14 & $\begin{array}{c}z 2.78 \mathrm{a} \\
(0.92)\end{array}$ & $\begin{array}{c}\text { y } 5.71 \mathrm{~b} \\
(1.02)\end{array}$ & $\begin{array}{l}0.30 \mathrm{c} \\
(0.02)\end{array}$ & $\begin{array}{l}0.31 \mathrm{c} \\
(0.03)\end{array}$ & $\begin{array}{c}3.15 \\
(0.81)\end{array}$ & $\begin{array}{c}3.07 \\
(0.26)\end{array}$ & $\begin{array}{c}1.16 \\
(0.09)\end{array}$ & $\begin{array}{c}1.14 \\
(0.08)\end{array}$ \\
\hline
\end{tabular}

* Average values of three $(n=3)$ independent determinations. Standard deviations are indicated in brackets.

${ }^{* *}$ For each quality index and for each icing time, mean values preceded by a different letter ( $y$, $z$ ) denote significant differences

$(p<0.05)$ between both icing conditions. For each parameter and for each icing condition, mean values followed by different letters $(a, b, c)$ denote significant differences $(p<0.05)$ as a result of icing time.

the gilthead seabream muscle (Pokorný, 1981; Aubourg, 1999) (Table 3). Similar conclusions were obtained for both fluorescence and browning property assessments. Thus, individuals corresponding to FI condition showed higher mean values than their counterparts from the SI system throughout the whole experiment; however, differences were not found significant. An increasing tendency with icing time could also be depicted for individuals from both icing conditions, although correlation values were not good $\left(r^{2}=0.79-0.88\right)$; however, differences as a result of an icing time increase were not significant (Table 3). A negligible formation of tertiary lipid oxidation compounds can be inferred, in comparison to the relatively low primary and secondary lipid oxidation compound formation observed (Table 3).

Fish species have attracted a great attention from consumers as a source of important nutritional PUFA (namely, docosahexaenoic and eicosapentaenoic acids) components for the human diet (Ackman, 1989; Simopoulos, 1997). Fatty acid analysis was carried out in the present study throughout the whole experiment. In all cases, the most abundant fatty acid was $\mathrm{C} 22: 6 \omega 3$ (docosahexaenoic acid,

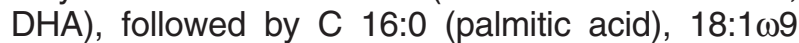

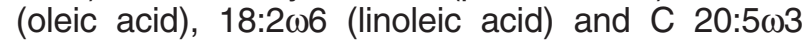
(eicosapentaenoic acid, EPA). Damage undergone by the polyunsaturated fatty acids (PUFA) during the present study was measured by the PI analysis. $A$ PI ranging from 1.5 and 2.0 was found in all kinds of samples (Figure 3 ). This value range can be considered similar to that previously reported for the same farmed species (Senso et al., 2007; Yildiz et al., 2008), in spite of the fact that a great dependence on the feed fatty acid composition has been determined (Yildiz et al., 2008; Fountoulaki et al., 2009).

In the present research, the $\mathrm{PI}$ did not provide differences $(p>0.05)$ among treatments at any of the icing times. In addition, no differences $(p>0.05)$ could be assessed as a result of the icing time for both chilling conditions. Previous research (Aubourg et al., 1998) has shown an important negative effect of lipid oxidation development on the PUFA content (PI decrease) during the chilled storage of a fatty fish species (sardine; Sardina pilchardus). However, in the present study, increases found for some lipid damage indexes have not produced a negative effect $(p>0.05)$ on the polyene index.

\section{CONCLUSIONS}

An important quality loss could be assessed in gilthead seabream during slaughtering and chilled storage, according to sensory analysis and TMA formation. However, lipid damage development was found low, according to the different lipid quality indexes considered (lipid hydrolysis; primary, secondary and tertiary lipid oxidation), these

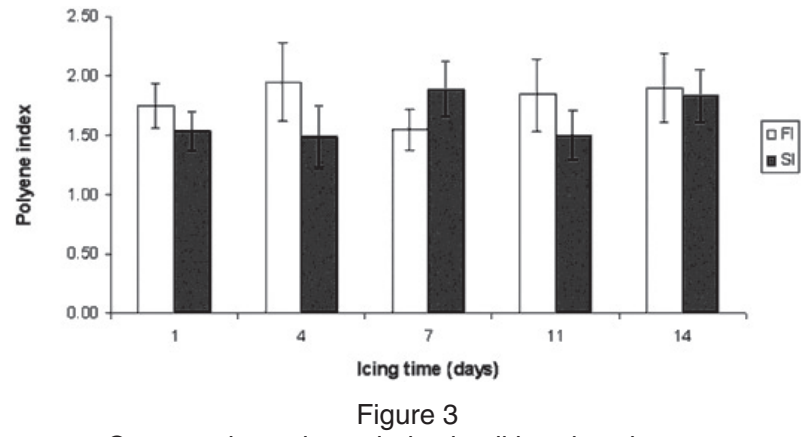

Comparative polyene index in gilthead seabream after slaughtering and chilled storage in flake ice (FI) or slurry ice $(\mathrm{SI})^{*}$, respectively. * Average values of three $(n=3)$ independent determinations. Standard deviations are indicated by bars. 
including no effect on the rancid odor development and no loss of polyunsaturated fatty acids.

The employment of $\mathrm{SI}$ as a slaughtering and chilling strategy was found useful in order to partially inhibit quality losses in gilthead seabream. Thus, a shelf life increase and a partial TMA and FFA formation inhibition could be obtained.

\section{ACKNOWLEDGEMENTS}

This work was supported through a project grant by the Secretaría Xeral de I+D from the Xunta de Galicia (Project PGIDIT 05 TAL 00701 CT). The authors thank Mr. Marcos Trigo for his excellent technical assistance and Cultipeix, S. L. (Valencia, Spain) for providing the farmed gilthead seabream fish.

\section{REFERENCES}

Ackman R. 1989. Fatty acids in Ackman R (Ed.) Marine Biogenic Lipids, Fats and Oils, Vol. 1, pp. 103-137. CRC Press, Boca Raton, FI, USA.

Alasalvar C, Taylor A, Shahidi F. 2002. Comparative quality assessment of cultured and wild sea bream (Sparus aurata) stored in ice. J. Agric. Food Chem. 50, 2039-2045.

Álvarez V, Feás X, Barros-Velázquez J, Aubourg S. 2009. Quality changes of farmed blackspot seabream (Pagellus bogaraveo) subjected to slaughtering and storage under flow ice and ozonised flow ice. Int. J. Food Sci. Technol. 44, 1561-1571.

Aubourg S, Medina I, Gallardo JM. 1998. Quality assessment of blue whiting (Micromesistius poutassou) during chilled storage by monitoring lipid damages. J. Agric. Food Chem. 46, 3662-3666.

Aubourg S, Medina I, Pérez-Martín R. 1996. Polyunsaturated fatty acids in tuna phospholipids: distribution in the sn-2 location and changes during cooking. J. Agric. Food Chem. 44, 585-589.

Aubourg S, Ugliano M. 2002. Effect of brine pre-treatment on lipid stability of frozen horse mackerel (Trachurus trachurus). Eur. Food Res. Technol. 215, 91-95.

Aubourg S. 1999. Recent advances in assessment of marine lipid oxidation by using fluorescence. J. Amer. Oil Chem. Soc. 76, 409-419.

Aubourg S. 2001. Fluorescence study of the pro-oxidant effect of free fatty acids on marine lipids. J. Sci. Food Agric. 81, 385-390.

Bligh E, Dyer W. 1959. A rapid method of total extraction and purification. Can. J. Biochem. Physiol. 37, 911917.

Caballero M, Betancor M, Escrig J, Montero D, Espinosa de los Monteros A, Castro P, Ginés R, Izquierdo M. 2009. Post mortem changes produced in the muscle of sea bream (Sparus aurata) during iced storage. Aquaculture, 291, 210-216.

Cakli S, Kilinc B, Cadun A, Dincer T, Tolasa S. 2006. Effect of ungutting on microbiological, chemical and sensory properties of aquacultured sea bream (Sparus aurata) and sea bass (Dicentrarchus labrax) stored in ice. Eur. Food Res. Technol. 222, 719-726.

Chaouqy NE, Gallardo JM, El Marrakchi A. Aubourg S. 2008. Lipid damage development in anchovy (Engraulis encrasicholus) muscle during storage under refrigerated conditions. Grasas y Aceites 59, 309-315.

Chapman R, McKay J. 1949. The estimation of peroxides in fats and oils by the ferric thiocyanate method. $J$. Amer. Oil Chem. Soc. 26, 360-363.

DOCE. 1989. Baremo de clasificación de frescura. In: Diario Oficial de las Comunidades Europeas, $\mathrm{n} \times \mathbf{L}$ 5/21, pp. 5-6. European Communities, Brussels, Belgium.

Erkan N. 2007. Sensory, chemical, and microbiological attributes of sea bream (Sparus aurata): Effect of washing and ice storage. Int. J. Food Propert. 10, 421-434.

FAO. 2007. Fishery statistics. Aquaculture production. In Food and Agriculture Organization of the United Nations, Yearbook 2005, Vol. 100/2, p. 84, Rome, Italy.

Fountoulaki E, Vasilaki A, Hurtado R, Grigorakis K, Karacostas I, Nengas I, Rigos G, Kotzamanis Y, Venou B, Alexis M. 2009. Fish oil substitution by vegetable oils in commercial diets for gilthead sea bream (Sparus aurata L.); effects on growth performance, flesh quality and fillet fatty acid profile. Recovery of fatty acid profiles by a fish oil finishing diet under fluctuating water temperatures. Aquaculture 289, 317-326.

Grigorakis K, Taylor K, Alexis M. 2003. Seasonal patterns of spoilage of ice-stored cultured gilthead sea bream (Sparus aurata). Food Chem. 81, 263-268.

Harris P, Tall J. 1994. Rancidity in fish in Allen J, Hamilton $\mathrm{R}$ (Eds.) Rancidity in foods, pp. 256-272. Chapman and Hall, London, UK.

Huidobro A, Mendes R, Nunes ML. 2001. Slaughtering of gilthead seabream (Sparus aurata) in liquid ice: influence on fish quality. Eur. Food Res. Technol. 213, 267-272.

Kilinc B, Cakli S, Cadun A, Dincer T, Tolasa S. 2007. Comparison of effects of slurry ice and flake ice pretreatments on the quality of aquacultured sea bream (Sparus aurata) and sea bass (Dicentrarchus labrax) stored at $4^{\circ} \mathrm{C}$. Food Chem. 104, 1611-1617.

Kyrana W, Laugovois V, Valsamis D. 1997. Assessment of shelf-life of maricultured gilthead sea bream (Sparus aurata) stored in ice. Int. J. Food Sci. Technol. 32, 339-347.

Labuza T. 1971. Kinetics of lipid oxidation in foods. CRC Critical Reviews in Food Technology 2, 355-405.

López-Caballero $\mathrm{M}^{\mathrm{a}} \mathrm{E}$, Huidobro A, Pastor A, Tejada M. 2002. Microflora of gilthead seabream (Sparus aurata) stored in ice. Effect of washing. Eur. Food Res. Technol. 215, 396-400.

Lougovois V, Kyranas E, Kyrana V. 2003. Comparison of selected methods of assessing freshness quality and remaining storage life of iced gilthead sea bream (Sparus aurata). Food Res. Intern. 36, 551-560.

Lowry R, Tinsley I. 1976. Rapid colorimetric determination of free fatty acids. J. Amer. Oil Chem. Soc. 53, 470472.

Medina I, Gallardo JM, Aubourg S. 2009. Quality preservation in chilled and frozen fish products by employment of slurry ice and natural antioxidants. Int. J. Food Sci. Technol. 44, 1467-1479.

Miyashita K, Takagi T. 1986. Study on the oxidative rate and prooxidant activity of free fatty acids. J. Amer. Oil Chem. Soc. 63, 1380-1384.

Olafsdóttir G, Martinsdóttir E, Oehlenschläger J, Dalgaard $\mathrm{P}$, Jensen B, Undeland I, Mackie I, Henehan G, Nielsen J, Nilsen H. 1997. Methods to evaluate fish freshness in research and industry. Trends Food Sci. Technol. 8, 258-265. 
Özogul F, Kuley E, Özogul Y. 2007. Sensory, chemical and microbiological quality parameters in sea bream (Sparus aurata) stored in ice or wrapped in cling film or in aluminium foil at $2 \pm 1{ }^{\circ} \mathrm{C}$. Int. J. Food Sci. Technol. 42, 903-909.

Pena J, Trigo M, Bouzada G, Fernández D, BarrosVelázquez J, Aubourg S. 2009. Chemical changes in chilled farmed sea bass (Dicentrarchus labrax): Effect of advanced icing conditions. Czech J. Food Sci. 27, S277-S2792.

Pigott G, Tucker B. 1990. Seafood: effects of technology on nutrition, pp. 66-84. Marcel Dekker Inc., New York, USA.

Pokorný J. 1981. Browning from lipid-protein interactions. Prog. Food Nutr. Sci. 5, 421-428.

Refsgaard H, Brockhoff P, Jensen B. 2000. Free polyunsaturated fatty acids cause taste deterioration of salmon during frozen storage. J. Agric. Food Chem. 48, 3280-3285.

Senso L, Suárez M, Ruiz-Cara T, García-Gallego M. 2007. On the possible effects of harvesting season and chilled storage on the fatty acid profile of the fillet of farmed gilthead seabream (Sparus aurata). Food Chem. 101, 298-307.

Simopoulos A. 1997. Nutritional aspects of fish in Luten J, Börrensen T, Oehlenschläger J. (Eds.) Seafood from producer to consumer, Integrated Approach to Quality, pp. 589-607. Elsevier Science, London, UK.

Smith G, Hole M, Hanson S. 1990. Assessment of lipid oxidation in Indonesian salted-dried marine catfish (Arius thalassinus). J. Sci. Food Agric. 51, 193-205.

Tejada M, Huidobro A, Mohamed F. 2003. Comparison of gilthead seabream (Sparus aurata) and hake
(Merluccius merluccius) muscle proteins during iced and frozen storage. J. Sci. Food Agric. 83, 113-122.

Tozawa H, Erokibara K, Amano K. 1971. Proposed modification of Dyer's method for trimethylamine determination in codfish in Kreuzer R. (Ed.) Fish Inspection and Quality Control, pp. 187-190. Fishing News Books Ltd., London, UK.

Vyncke W. 1970. Direct determination of the thiobarbituric acid value in trichloracetic acid extracts of fish as a measure of oxidative rancidity. Fette Seifen Anstrichm. 72, 1084-1087.

White P. 1994. Conjugated diene, anisidine value and carbonyl value analyses in Warner K, Eskin M. (Eds.) Methods to assess quality and stability of oils and fat-containing foods, pp. 159-178. AOCS Press, Champaign, Illinois, USA.

Whittle K, Hardy R, Hobbs G. 1990. Chilled fish and fishery products in Gormley T. (Ed.) Chilled foods: The state of the art, pp. 87-116. Elsevier Applied Science, New York, USA.

Yamada M, Fukusako S, Kawanami T. 2002. Performance analysis on the liquid-ice thermal storage system for optimum operation. Int. J. Refrig. 25, 267-277.

Yildiz M, Sener E, Timur M. 2008. Effect of differences in diet and seasonal changes on the fatty acid composition in fillets from farmed and wild sea bream (Sparus aurata L.) and sea bass (Dicentrarchus labrax). Int. J. Food Sci. Technol. 43, 853-858. 